\title{
Галкина Н.M.
}

\section{Теоретические подходы к развитию профессиональной компетентности слушателя в самообучающейся системе дополнительного (последипломного) образования}

\author{
Galkina N.M. \\ Theoretical approaches to the development of professional \\ competence of the listener in a self-learning system \\ of additional (postgraduate) education
}

На основе теоретического анализа

коммуникативной компетентности специалиста в структуре его профессиональной деятельности (в психологии, философии, социологии) сделано заключение, что коммуникативная компетентность специалиста - это ключевая социально-профессиональная компетентность, обеспечивающая успешность профессионального роста специалиста как самоорганизующейся личности, его конкурентоспособность и успешность в условиях мирового экономического спада

Ключевые слова: дополнительное профессиональное (послевузовское) образование, инновационность, профессиональная

компетентность, коммуникативная система

Галкина Нина Михайловна

Кандидат педагогических наук, декан

Азовского технологического института филиал ДГТУ

2. Азов, ул. Промышленная, 1

\begin{abstract}
Based on the theoretical analysis of the communicative competence of the expert in the structure of his professional activity (in psychology, philosophy, sociology) concluded that the communicative competence of a specialist - a key social and professional competence to ensure the successful professional development specialist as a self-organizing individual competitiveness and success in the conditions the global economic downturn
\end{abstract}

Key words: additional professional (post-graduate) education, innovation, professional competence, communicative system

\section{Galkina Nina Michailovna}

Candidate of Pedagogical Sciences, Dean

Azov technological institute branch of DSTU

Azov, Industrial st., 1

В педагогике значимость социальной сущности коммуникативной компетенции подчеркивает И.А. Зимняя, выделяя три основные группы компетентностей: 1) относящиеся к самому себе как личности, субъекту жизнедеятельности, 2) к взаимодействию человека с другими людьми; 3) к деятельности человека. При этом автор отмечает, что все компетентности социальны в широком смысле этого слова, ибо формируются в социуме. Они социальны по своему содержанию и проявляются в нем. При этом в структуре социальных компетенций выделены компетентности социального взаимодействия, общения, 
информационно-технологическая. Значимость этих компонентов и позволяет нам выделить в качестве предмета изучения в своем исследовании, коммуникативную компетенцию специалиста, определить ее в качестве ключевой. Ключевые - это обобщенно представленные основные компетентности, обеспечивающие нормальную жизнедеятельность человека в социуме; профессиональные и учебные компетентности - формируются и проявляются в этих видах деятельности человека [7].

Согласно позиции В.И. Байденко и др., в перечень востребованных работодателями социальных компетенций входят: 1) коммуникативность (отзывчивость в общении, структурированность речи, убедительность аргументации, обращение с возражениями и т.д.); 2) способность работать в команде; 3) умение наглядно и убедительно проводить презентацию своих идей; 4) готовность к нестандартным, креативным решениям; 5) навыки самоорганизации; 6) гибкость в отношении вновь появляющихся требований и изменений; 7) выносливость и целеустремленность [1:2]. Такой подход ориентирует нас на обращение к результатам исследования коммуникативной компетенции в рамках социально-психологического подхода (Ю.Н. Емельянов, Л.А. Петровская, Ю.М. Жуков и др. ), сторонники которого считают, что коммуникативная компетенция не возникает стихийно, а формируется в системе обучающих и развивающих мероприятий. При этом подчеркивается значимость развития этических характеристик и ценностных ориентаций профессионала, адекватных гуманистическим принципам общения. Как показано рядом авторов, в ситуациях профессионального общения основополагающую роль играет доверие к личности и профессионализму коммуникатора [9].

Таким образом, рассматривая коммуникативную компетентность специалиста и выделяя коммуникативную компетенцию в качестве ключевой компетенции специалиста, осуществляющего профессиональную деятельность, необходимо обратиться к конкурентности как внешнему условию, оптимизирующему развитие дополнительного образования как структурного компонента вуза - открытой системы, следует подверкнуть взаимосвязь категорий коммуникативная компетенция и конкурентоспособность специалиста.

Конкурентоспособность как интегральное, универсальное, социальноличностное качество, формирующееся на основе культуры человека, обусловленное ценностными нормами и традициями, необходимое для активного участия в различных видах деятельности, базирующееся на профессиональной, межличностной, социальной и интеллектуальной компетентности и личностных качествах (Герниченко А.). Модель подготовки конкурентоспособного специалиста включает потребность в непрерывном образовании, корпоративную культуру, сформированность инвариантной и вариативной деятельности; готовность к работе на рабочем месте [3; 4, 8 и др.].

Изучение исследований по самоорганизации личности (Ю.Н. Белокопытов, А.Д. Ишков, Т.А. Каплунович, С.Н. Капустин, Е.Н. Князева, Г.В. Коган, В.Н. Корчагин, В.А. Халанская и др.) позволяет сделать вывод о том, что личность является самоорганизующейся системой. В качестве механизма самоорганизации выступает рефлексия, выполняющая функцию обратной связи, являющей- 
ся основным признаком и условием самоорганизации. С учетом данного подхода уместно рассмотреть позицию Э.Ф. Зеер. Структура коммуникативной компетенции включает следующие составляющие: 1) персональная компетентность как способность к постоянному профессиональному росту и повышению квалификации, а также реализации себя в профессиональном труде; 2) аутокомпетентность - адекватное представление о своих социальнопрофессиональных характеристиках и владение технологиями преодоления профессиональных деструкций [5; 6].

Сложность реализации цели профсовершенствования в системе дополнительного образования связана с тем, что у большинства молодых специалистов (выпускников вузов) отсутствует потребность в самостоятельном сознательном приобретении новых научных и профессиональных знаний, их осмыслении, и как следствие, в саморазвитии и самовоспитании, без которых не может состояться специалист-профессионал как новатор, способный продвигать научно-технический прогресс. Вместе с тем, в современной системе дополнительного образования при решении творческих профессиональных задач слушатель обязательно сталкивается с необходимостью самостоятельного поиска дополнительной информации, то есть, поиском новых для себя знаний. С педагогической точки зрения, поиск слушателем в процессе обучения информации может служить фактором, мотивирующим формирование и развитие его коммуникативной компетенции.

В результате проведенного анализа теоретических подходов к определению компетентности, профессиональной компетентности, коммуникативной компетентности в философии, социологии, психологии, теории профессионального образования, сформулировано следующее определение коммуникативной компетентности специалиста - это ключевая социальнопрофессиональная компетентность, обеспечивающая успешность профессионального роста специалиста как самоорганизующейся личности, его конкурентоспособность и успешность в условиях мирового экономического спада. В структуре коммуникативной компетентности специалиста интегрируются характеристики информационно-технологической компетентности, компетентности социального взаимодействия и компетентности общения. Развитие коммуникативной компетентности слушателя основано на его самореализации, мотивации и готовности к самосовершенствованию и т.д. и возможно в условиях самообучающейся системы.

Учитывая специфику деятельности открытых систем, к которым относим современный вуз и систему ДПО как его инфраструктуру, а также, рассматривая условия профессионального совершенствования слушателя в системе ДПо, необходимо рассматривать понятие «взращивание компетенции» до уровня компетентности, которое задает аспекты рассмотрения дидактической модели ДПО.

\section{Список используемых источников:}

1. Байденко В.И., Джерри ван Зантворт, Бианка Енеке. Формирование социального диалога и партнерских связей образования, органов управления и саморазвития, профессиональных объединений и предприятий. ТАСИС, проект ДЕЛФИ. Доклад 4, апрель, 2001. 
2. Безлепкин В., Власов В., Пименова Е. Государственный интерес: о дополнительном профессиональном образовании // Высш. образование России. 1998.

3. Вирина И.В. Проблемы конкурентоспособности молодых специалистов на рынке труда // Высшее образование для ХХІ века: вторая международная научная конференция, МосГУ: Социальное образование. Ч. З. М.: Изд-во МосГУ, 2005.

4. Герниченко А.А. Подготовка конкурентоспособных выпускников среднего профессионального образования для энергетики. Новокузнецк. 2006.

5. Захаревич В.Г., Попов В.П., Каркищенко А.Н., Заграй Н.П. Международная аккредитация в АВЕТ как основа академической мобильности. Таганрог: Изд-во ТРТУ, 2003.

6. Зборовский Г., Щуклина Е. Самообразование как парадигма ХХІ в. // Высшее образование в России. 2003. № 5 .

7. Зимняя И.А. Ключевые компетенции - новая парадигма результата образования // Высшее образование сегодня. № 5. 2003.

8. Петровская Л.А. О понятийных схемах социально-психологического анализа категорий // Социально-психологические тексты для подготовки к семинарским занятиям. М.: ФП МГУ, 1998. 9. Тротиньон Ж-П. Профессиональная подготовка инженеров международного уровня. Сеть «n+i» (Агентство EduFrance, Франция). URL: http://www.nplusi.com

(C) 2015, Галкина Н.M.

Теоретические подходы к развитию профессиональной компетентности слушателя в самообучающейся системе дополнительного (последипломного) образования
(C) 2015, Galkina N.M.

Theoretical approaches to the development of professional competence of the listener in a selflearning system of additional (postgraduate) education 